\title{
fAFLP analysis of Brazilian Bacillus thuringiensis isolates
}

Fernando Hercos Valicente ${ }^{1 *}$ and Rosane Bezerra da Silva ${ }^{2}$

\begin{abstract}
A total of 65 Bacillus thuringiensis (Bt) isolates were subjected to analysis of genetic relationship using fAFLP (fluorescent Fragment Length Polymorphism), in order to determine the genetic diversity within a group of Bt strains. 26 strains from different subspecies were identified as it follows: 9 kindly provided by the USDA (United States Department of Agriculture), 9 kindly provided by the Institute Pasteur and eight from Embrapa Maize and Sorghum Bt Collection, and 39 strains with no subspecies information also from Embrapa's Bt Collection. DNA sample was double digested with restriction enzymes EcoRl and Msel, and the fragments were linked to adapters. Selective amplification reactions were performed using five primer combinations and the amplified fragments were separated by gel electrophoresis on an ABI377 sequencer. Genetic distances were obtained by the complement of the Jaccard coefficient and the groups were performed by the UPGMA method. Five primer combinations generated 495 scorable fragments and 483 were found to be polymorphic. Out of 26 subspecies, strains 344 and T09 (B. thuringiensis subsp. tolworthi) showed the highest similarity (15\%), while isolates HD3 B. thuringiensis subsp finitimus and T24 B. thuringiensis subsp neoleonensis were the most genetically distant (92\%). B. thuringiensis isolates with no subspecies identification, found in samples from Goiás State showed higher similarity forming a group with an average distance of $6 \%$, and the closest subspecies to this group was B. thuringiensis subsp thuringiensis (HD2) with $52 \%$ of similarity. This similarity may be due to the fact that these organism exchange genetic material by conjugation, and it is relatively common to have evolutionary characteristics of their ancestors.
\end{abstract}

Keywords: AFLP; Genetic diversity; Bacillus thuringiensis; Restriction enzymes

\section{Background}

Bacillus thuringiensis (Bt) is a rod-shaped, Gram-positive soil bacterium characterized by its ability to produce crystalline inclusions called "Cry proteins, Cry toxins or Bt toxins" during sporulation. The crystalline inclusions along with the spores have a high potential to control a great number of insect pests belonging to the order Lepidoptera, Diptera and Coleoptera (Vidyarthi et al. 2002; Yamamoto and Dean 2000). B. thuringiensis can be found in different substrates such as soil, water, plant surfaces, dead insects, grain dust, and stored grain (Glare and O'Callaghan 2000; Valicente and Barreto 2003), and it is a useful alternative or zment to synthetic chemical pesticide applications in commercial agriculture, horticulture, forest management, and mosquito control (De Maagd et al.

\footnotetext{
*Correspondence: fernando.valicente@embrapa.br

'Embrapa Milho e Sorgo, Rod. MG 424 KM 65, CEP 35701-970 Sete Lagoas, MG, Brazil

Full list of author information is available at the end of the article
}

1999). B. thuringiensis also has high genetic variability and are widely distributed in nature (Vilas-Boas et al. 2002, Martin and Travers 1989, Hossain et al. 1997). The polymerase chain reaction (PCR) has been used to identify specific cry genes and characterize $B$. thuringiensis strains with a high degree of success (Chak et al. 1994; Cerón et al. 1994, 1995; Shangkuan et al. 2001; Lima et al. 2002; Valicente et al., 2010).

The Amplified Fragment Length Polymorphism (AFLP) technique is based on the detection of genomic restriction fragments by PCR amplification, and can be used for DNAs of any origin or complexity (Vos et al. 1995). AFLP may be used as a tool for bacterial taxonomy and has shown utility in detecting molecular variability in very closely related bacterial strains (Jansen et al. 1997; Burke et al. 2004; Grady et al. 2001). The fAFLP (flurescent Amplified Fragment Length Polymorphism) use markers with fluorescent substances, the use of primers labeled with a fluorochrome, associated with automatic sequencers and a

\section{实 Springer}


large capacity for computational analysis (Ryu et al. 2005; Burke et al. 2004).

Spodoptera frugiperda (Smith) is responsible for significant losses in maize production in Brazil. Its control is mainly achieved using chemical insecticides. However, biological control using $B$. thuringiensis and the production of genetically modified plants with insect resistance genes are excellent alternatives to control this insect (Valicente and Barreto 2003).

The purpose of the present study was to use fAFLP for molecular analysis and characterization of $B$. thuringiensis strains that were previously tested against $S$. frugiperda, and to determine the degree of genetic variability and correlation between different genotypes of public strains of $B$. thuringiensis and strains sampled in different Brazilian regions.

\section{Materials and methods}

\section{B. thuringiensis strains}

Of a total of $65 \mathrm{~B}$. thuringiensis strains used in this research (Table 1), 26 strains from different subspecies were identified as it follows: 9 kindly provided by the

Table 1 Bacillus thuringiensis serovars used in this study, with mortality against fall armyworm, Spodoptera frugiperda

\begin{tabular}{|c|c|c|c|c|c|c|c|c|}
\hline $\mathrm{N}^{\circ}$ & Bt subspecies & $\begin{array}{c}\text { Strain } \\
\text { identification }\end{array}$ & Mortality (\%)* & Origin & $\mathbf{N}^{\circ}$ & $\begin{array}{c}\text { Strain } \\
\text { identification }\end{array}$ & Mortality (\%)* & Origin \\
\hline 1 & alesti & $\mathrm{HD}-4$ & 6.8 & USA & 34 & $1109 \mathrm{~N}$ & 100 & Goiás State/Brazil \\
\hline 2 & alesti & $348 B$ & 100 & Paraná State/Brazil & 35 & $1145 B$ & 100 & Goiás State/Brazil \\
\hline 3 & aizawai & $\mathrm{T}-07$ & 80.8 & France & 36 & $1145 C$ & 100 & Goiás State/Brazil \\
\hline 4 & aizawai & HD-11 & 7.8 & USA & 37 & $1148 \mathrm{~F}$ & 100 & Goiás State/Brazil \\
\hline 5 & galleriae & $462 \mathrm{~A}$ & 100 & Paraná State/Brazil & 38 & $1132 \mathrm{E}$ & 100 & Goiás State/Brazil \\
\hline 6 & galleriae & 474 & 100 & Paraná State/Brazil & 39 & $1135 B$ & 100 & Goiás State/Brazil \\
\hline 7 & galleriae & $348 L$ & 100 & Paraná State/Brazil & 40 & $1136 \mathrm{~B}$ & 100 & Goiás State/Brazil \\
\hline 8 & galleriare & HD-29 & 12.8 & USA & 41 & $1139 \mathrm{~K}$ & 100 & Goiás State/Brazil \\
\hline 9 & tolworthi & 344 & 100 & Paraná State/Brazil & 42 & BTLM & 100 & Goiás State/Brazil \\
\hline 10 & tolworthi & T-09 & 100 & Françe & 43 & 1644 & 100 & Paraná State/Brazil \\
\hline 11 & tolworthi & 426 & 100 & Ceará State/Brazil & 44 & 1641 & 100 & Paraná State/Brazil \\
\hline 12 & tolworthi & $461 \mathrm{~A}$ & 100 & Paraná State/Brazil & 45 & $701 \mathrm{~A}$ & 100 & São Paulo State/Brazil \\
\hline 13 & darmstadiensis & 460 & 100 & Paraná State/Brazil & 46 & 1658 & 100 & São Paulo State/Brazil \\
\hline 14 & darmstadiensis & $\mathrm{T}-10$ & 77.9 & France & 47 & 1646 & 100 & São Paulo State/Brazil \\
\hline 15 & entomocidus & $\mathrm{T}-06$ & 9.8 & France & 48 & $701 B$ & 100 & São Paulo State/Brazil \\
\hline 16 & neoleonensis & $\mathrm{T}-24$ & 17.9 & France & 49 & 1648 & 100 & São Paulo State/Brazil \\
\hline 17 & mexicanensis & $\mathrm{T}-27$ & 17 & France & 50 & 1438 & 100 & Sergipe State/Brazil \\
\hline 18 & japonensis & $\mathrm{T}-23$ & 33.5 & France & 51 & $1438 \mathrm{H}$ & 100 & Sergipe State/Brazil \\
\hline 19 & indiana & $\mathrm{T}-16$ & 12.2 & France & 52 & 1089E & 95.8 & Minas Gerais/State/Brazil \\
\hline 20 & kurstaki & HD-73 & 2.7 & USA & 53 & $1091 \mathrm{H}$ & 95.8 & Minas Gerais State/Brazil \\
\hline 21 & kurstaki & HD-1 & 0 & USA & 54 & $1604 \mathrm{D}$ & 95.2 & Amazônia State/Brazil \\
\hline 22 & morrisoni & HD-12 & 28 & USA & 55 & 1605 & 95.2 & Amazônia State/Brazil \\
\hline 23 & dendrolimus & $\mathrm{HD}-7$ & 5.4 & USA & 56 & 1657 & 100 & Amazônia State/Brazil \\
\hline 24 & finitimus & HD-3 & 5.2 & USA & 57 & 1656 & 100 & Alagoas State/Brazil \\
\hline 25 & thuringiensis & $\mathrm{HD}-2$ & 37.8 & USA & 58 & $1603 B$ & 100 & Santa Catarina State/Brazil \\
\hline 26 & israelensis & $\mathrm{T}-14$ & 0 & France & 59 & $1626 C$ & 97.6 & Maranhão State/Brazil \\
\hline 27 & & $1119 C$ & 100 & Goiás State/Brazil & 60 & 702 & 97.6 & Mato Grosso State/Brazil \\
\hline 28 & & $1124 \mathrm{E}$ & 100 & Goiás State/Brazil & 61 & 1354 & 100 & Minas Gerais State/Brazil \\
\hline 29 & & $1131^{\mathrm{A}}$ & 100 & Goiás State/Brazil & 62 & $1355 S L O$ & 100 & Minas Gerais State/Brazil \\
\hline 30 & & $1131 C$ & 100 & Goiás State/Brazil & 63 & $1357 \mathrm{E}$ & 100 & Paraná State/Brazil \\
\hline 31 & & $1132^{\mathrm{A}}$ & 100 & Goiás State/Brazil & 64 & 566 & 100 & Paraná State/Brazil \\
\hline 32 & & $1132 C$ & 100 & Goiás State/Brazil & 65 & $1355 \mathrm{LM}$ & 100 & Minas Gerais State/Brazil \\
\hline 33 & & $1138 \mathrm{G}$ & 100 & Goiás State/Brazil & & & & \\
\hline
\end{tabular}

*Mortality results from Valicente and Barreto 2003 and Valicente and Fonseca 2004. 
USDA (United States Department of Agriculture), 9 kindly provided by the Institute Pasteur and eight from Embrapa Maize and Sorghum Bt Collection. Also, 39 strains with no subspecies information also from Embrapa's Bt Collection (Table 1). The words subspecies and serovar were used interchangeably as given by Zeigler (1999). All strains have been previously tested against fall armyworm, S. frugiperda (Lepidoptera: Noctuidae J.E. Smith) (Valicente and Fonseca 2004; Valicente and Barreto 2003), and showed different toxicity activity. These strains are stored in glycerol in a freezer at $-20^{\circ} \mathrm{C}$.

\section{Bacterial cultures}

B. thuringiensis isolates were inoculated into $5 \mathrm{ml} \mathrm{LB}$ medium enriched with salts and glucose (all expressed in $\mathrm{g.l}^{-1}, 0.002 \mathrm{~g}$ of FeSO4, $0.02 \mathrm{~g}$ of $\mathrm{ZnSO} 4,0.02 \mathrm{~g}$ of $\mathrm{MnSO} 4,0.3 \mathrm{~g}$ of $\mathrm{MgSO} 4)$ and $2 \%$ glucose, with $\mathrm{pH}$ adjusted to 7.2. The shaking flasks were incubated at a stirrer speed of $250 \mathrm{rpm}$ for $16 \mathrm{~h}$ at $28^{\circ} \mathrm{C}$. Colonies were observed on a phase contrast microscope.

\section{DNA extraction}

Genomic DNA from B. thuringiensis strains was isolated and purified according to Shuhaimi et al. (2001) with modifications. A volume of $5 \mathrm{ml}$ of an overnight culture was centrifuged at $4600 \mathrm{~g}$ for $5 \mathrm{~min}$. The pellet was washed with sterile distilled water and resuspended in $700 \mu \mathrm{l}$ glucose/Tris/EDTA buffer $(50 \mathrm{mM}$ glucose, $25 \mathrm{mM}$ Tris/HCl and $10 \mathrm{mM}$ EDTA, $\mathrm{pH}$ 8). Lysozyme was added to the bacterial suspension at $20 \mathrm{mg} / \mathrm{ml}$ and incubated at $37^{\circ} \mathrm{C}$ for $30 \mathrm{~min}$. The cells were additionally lysed by adding $15 \mu \mathrm{l} 20 \%(\mathrm{w} / \mathrm{v})$ SDS. Five $\mu \mathrm{l}$ of proteinase $\mathrm{K}$ at $20 \mathrm{mg} / \mathrm{ml}$ was added and incubated at $65^{\circ} \mathrm{C}$ for $1 \mathrm{~h}$ to complete protein digestion. Five hundred $\mu \mathrm{l}$ of Phenol/ chloroform/isoamyl alcohol (25:24:1 by vol.) was added and centrifuged at $12.000 \mathrm{~g}$ for $1 \mathrm{~min}$. Three hundred $\mu \mathrm{l}$ of the aqueous upper layer was then transferred into a sterile new tube and an equal volume of $3 \mathrm{M}$ potassium acetate ( $\mathrm{pH}$ 5.2), and a double volume of 2-propanol were added. The mixture was then centrifuged at $12.000 \mathrm{~g}$ for $7 \mathrm{~min}$. The supernatant was carefully discarded. The pellet was washed with $70 \%(\mathrm{v} / \mathrm{v})$ ethanol by centrifuging at $12.000 \mathrm{~g}$ for $5 \mathrm{~min}$. The ethanol was discarded and the pellet containing the chromosomal DNA resuspended in $150 \mu \mathrm{l}$ of Tris-EDTA pH $8.0(10 \mathrm{mM}$ Tris-HCl, $1 \mathrm{mM}$ EDTA) and stored at $-20^{\circ} \mathrm{C}$ until further use.

\section{fAFLP analysis of DNA samples}

The fAFLP reactions were performed using to the Applied Biosystems AFLP $^{\mathrm{m}}$ microbial fingerprinting Kit with the genomic DNA (500 ng) being digested with $5 \mathrm{U}$ EcoRI and 2,5 U of MseI (Invitrogen ${ }^{\circ}$, Carlsbad, CA, EUA) in 1,25 $\mu \mathrm{l}$ of buffer $10 \times$ with final volume of $10 \mathrm{uL}$. After the digestions, were added $1 \mu \mathrm{l}$ of EcoRI and MseI adapters
(2 mM), $1.5 \mathrm{U}$ of T4 DNA ligase buffer with T4 DNA ligase of $(50 \mathrm{mM}$ Tris- $\mathrm{HCl}, \mathrm{pH} 7.8,10 \mathrm{mM} \mathrm{MgCl}$, $10 \mathrm{mM}$ dithiothreitol, $1 \mathrm{mM}$ ATP, $25 \mathrm{~g} / \mathrm{ml}$ bovine serum albumin). The binding reactions were conducted at $20^{\circ} \mathrm{C}$ for $2 \mathrm{~h}$, and amplicons produced were dissolved in $30 \mu \mathrm{l}$ of TE buffer (10 mM Tris-HCl, $1 \mathrm{mM}$ EDTA, $\mathrm{pH}$ 8.0) and used as template in pre-selective amplification reactions. The binding sites of pre-selective primers are the sequences of the adapters of restriction sites that provide a selection of restriction fragments obtained. The reactions were obtained using a $2 \mu \mathrm{l}$ of diluted DNA, $7.5 \mu \mathrm{l}$ of Core Mix and $0.5 \mu \mathrm{l}$ of EcoRI primers $(1 \mu \mathrm{M})$ and MseI $(5 \mathrm{mM})$ were considered as pre-selective. Amplification conditions were: $72^{\circ} \mathrm{C}$ for 2 minutes, 20 cycles starting at $94^{\circ} \mathrm{C}$ for $20 \mathrm{~s}, 56^{\circ} \mathrm{C}$ for $30 \mathrm{~s}$ and $72^{\circ} \mathrm{C}$ for 2 minutes. Products amplification were electrophoresed on $0.8 \%$ agarose gels and subsequently stained colored with ethidium bromide $(0.5 \mathrm{mg} / \mathrm{ml})$, and observations about the presence of bands at most of $500 \mathrm{bp}$. The pre-amplified products were diluted (1:15) with TE buffer and $1.5 \mu \mathrm{l}$ were used in the pre-amplification reaction along with $7.5 \mu \mathrm{l}$ of buffer, nucleotides and AmpliTaq DNA polymerase, a mixture called "Core Mix, $0.5 \mu \mathrm{l}$ of the MseI primer $(5 \mu \mathrm{M})$ and $0.5 \mu \mathrm{l}$ of EcoRI primer, labeled with fluorescence $(1 \mu \mathrm{M})$. Selective amplifications were performed in $20 \mu \mathrm{l}$ reactions with the following steps: $94^{\circ} \mathrm{C}$ for $30 \mathrm{~s}, 65^{\circ} \mathrm{C}$ for $30 \mathrm{~s}$, and $72^{\circ} \mathrm{C}$ for $1 \mathrm{~min}$ for 1 cycle and then lowering the annealing temperature by $1^{\circ} \mathrm{C}$ each cycle to $56^{\circ} \mathrm{C}$, followed by an additional 20 cycles at a $56^{\circ} \mathrm{C}$. Five primer combinations were used in the selective amplification $(E c o R I-A C+$ MseI -CG; EcoRI -G + MseI -CC; EcoRI -C + MseI -G; EcoRI -0 + MseI -CG; EcoRI -C + MseI -CG).

\section{Sequencing eletrophoresis of polyacrylamide gel and data analysis}

Each sample was loaded onto a 5\% Long-Ranger denaturing gel which was run in an ABI PRISMTM 377 DNA Sequencer (PE-Applied Biosystems) for $4 \mathrm{~h}$ at $2,500 \mathrm{~V}$. The electrophoresis images obtained from each reaction were analyzed using the GENESCAN program version 3.1 (Applied Biosystems). The Genotyper program version 2.5 (Applied Biosystems) was used to

$\begin{aligned} & \text { Table } 2 \text { AFLP primer combinations used for the } \\
& \text { fingerprinting of Bt serovars strains. }\end{aligned}$
\begin{tabular}{lcc}
\hline $\begin{array}{l}\text { Primer } \\
\text { combination }\end{array}$ & $\begin{array}{c}\text { Number of } \\
\text { fragments }\end{array}$ & $\begin{array}{c}\text { Number of polymorphic } \\
\text { fragments }\end{array}$ \\
\hline *ECOR1-AC+Mse1-CG & 77 & 74 \\
*ECOR1-G + Mse1-CC & 96 & 89 \\
*ECOR1-C + Mse1 - G & 130 & 129 \\
*ECOR1-0 + Mse1-CG & 113 & 112 \\
$*$ ECOR1-C + Mse1-CG & 79 & 79
\end{tabular}

${ }^{*}$ AFLP primer combinations. 
check the presence (coded as 1) or absence (coded as 0 ) of polymorphic bands in the electropherograms, and produce a binary matrix and the GENES program version 2008 (Cruz 2001). The genetic relationships among strains were evaluated using a matrix of genetic distances using the complement of the Jaccard similarity coefficient (CSJ), that does not consider negative similarities and the absence of the product (Cruz and Carneiro 2006). From estimates of the dissimilarities, the lines were grouped using hierarchical UPGMA method (Unweighted Pair-Group Mean Average) with the test of bootstrap (1000 times) to evaluate the consistency of the group (Efron and Tibshirani 1993).

\section{Results and discussion}

In this study we have examined the genetic variation among isolates of $B$. thuringiensis. fAFLP markers generated excellent results in characterizing molecular

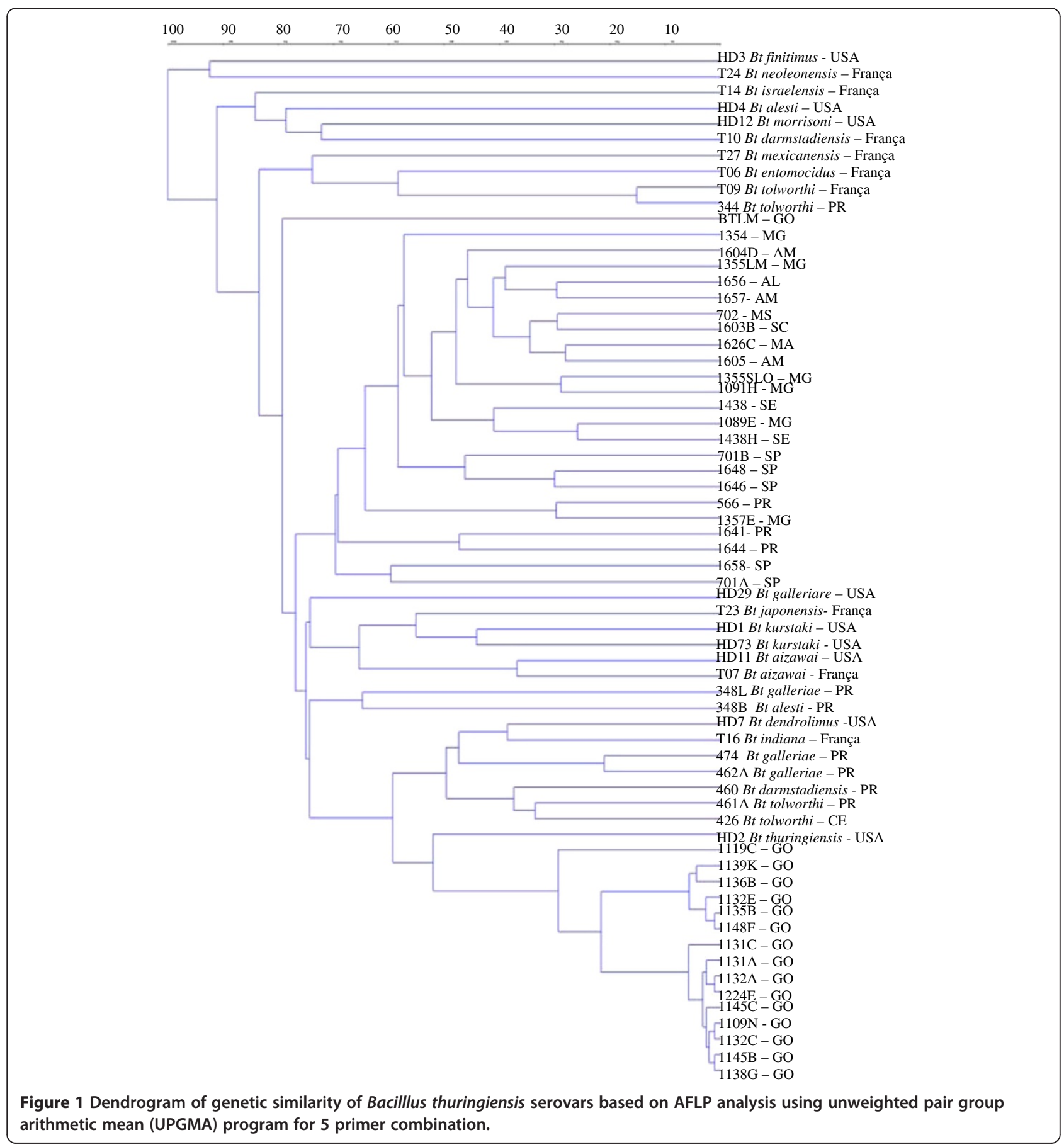


diversity and genetic relationship within the species of tropical isolates of B. thuringiensis. A total of 495 scorable fragments were generated, ranging from 50 to $500 \mathrm{bp}$, in the $65 \mathrm{~B}$. thuringiensis strains when 5 primer combinations were used. Out of 495 fragments 483 were found to be polymorphic, and only 12 fragments were monomorphic (Table 2), and 7 of these fragments were generated by the primer combination EcoR1-G + Mse1-CC. Our results showed that the EcoRI primer with selective nucleotide Mse1-C and Mse1-CG generated the greatest number of fragments, 130 and 113, respectively. However, EcoRI primer with selective nucleotide AC and C with selective nucleotide Mse1-CG generated fewer fragments, 77 and 79, respectively.

Genetic distances were obtained using the complement of the Jaccard similarity coefficient (CSJ), and the grouping using hierarchical UPGMA method. Genomic AFLP markers were analyzed through UPGMA cluster analysis to determine the genetic relationship among B. thuringiensis isolates (Figure 1). Out of 26 subspecies, strains 344 and T09 (B. thuringiensis subsp. tolworthi) showed the highest similarity (15\%), while isolates HD3 B. thuringiensis subsp finitimus and T24 B. thuringiensis subsp neoleonensis were the most genetically distant (92\%). B. thuringiensis isolates with no subspecies identification, found in samples from Goiás State showed higher similarity forming a group with an average distance of $6 \%$, and the closest subspecies to this group was B. thuringiensis subsp thuringiensis (HD2) with $52 \%$ of similarity. Groups with high similarity were formed with B. thruingiensis strains collected in the same State, and other groups composed with $B$. thruingiensis strains collected in different Brazilian regions. No polymorphism was found as a reliable marker among Bt strains efficient and not efficient against fall armyworm.

Among the 65 B. thuringiensis strains analyzed, 15 formed a single major cluster, and coincidently these strains were sampled in the same Brazilian State, however more than $200 \mathrm{~km}$ apart. The phylogenetic analysis of these Brazilian soil isolates (Figure 1) illustrates the great genetic diversity among strains in the same serovar. However, B. anthracis in a previous analysis of a global collection of 78 strains showed little variation among the isolates.

Kumar et al. 1996 found that the low level of similarity between different $B$. thuringiensis subspecies or strains used in his research implied in high levels of genetic diversity which was reflected by the diversity in flagellar $\mathrm{H}$-antigen agglutination reactions and presence of different toxins with different insect specificities. According to Aronson et al. 1986, several factors may contribute to the genetic diversity of $B$. thuringiensis strains, such as the presence of many different plasmids in size and numbers in each strain, and transfer of plasmids via cell mating. Fagundes et al. 2011, found that the number and size of plasmids varied between different strains in the same serovar, however the isolates from Goías State showed similar plasmid profiles, and these informations suggest that these isolates harbor common genes. Carlson, et al. 1996 also reported that the presence or absence of one or more large plasmids and they may be linear or circular during analysis. B. anthracis harbors two plasmids and plasmids of similar size have been reported in $B$. cereus and B. thuringiensis. These observations support the idea that horizontal gene transfer of plasmid and/or other extrachromosomal markers is an important factor in defining the phenotypes of type I bacillus $B$. cereus-like isolates evolved along apparent large evolutionary distances to give rise to clusters that in more recent times acquired plasmids that conferred insecticidal or other pathogenic phenotypes (Hill et al. 2004). These observations of genetic diversity were also reflected in our results. Lereclus et al. 1984 mentioned that the transposon-like inverted repeats flanking the endotoxin genes are also a factor of genetic diversity.

Few studies have been published using the fAFLP technique to characterize $B$. thuringiensis isolates, but we concluded that AFLP is a highly reproducible, easy to use and relatively fast method which can be applied to different organisms, which can be used for genetic diversity studies, and seems particularly well suited for screening a large numbers of isolates. Moreover, the same protocol can be used in screening at the subspecies level, and demonstrated the value of AFLP technique for the study of diversity between strains of $B$. thuringiensis.

\section{Competing interests}

The authors declare that they have no competing interests.

\section{Authors' contributions}

RBS carried out the AFLP analysis and dendrogram of genetic similarity. FHV drafted the manuscript and helped to whole analysis of data. Both authors approve the final manuscript.

\section{Author details}

${ }^{1}$ Embrapa Milho e Sorgo, Rod. MG 424 KM 65, CEP 35701-970 Sete Lagoas, MG, Brazil. ²Department of Biotechnology, Campus Universitário, CEP

37200-000 Lavras, MG, Brazil.

Received: 25 October 2013 Accepted: 10 April 2014

Published: 20 May 2014

\section{References}

Aronson Al, Beckman W, Dunn P (1986) Bacillus thuringiensis and related insect pathogens. Microbiol Rev 30:1-24

Burke SA, Wright MK, Robinson MK, Bronk BV, Warren RL (2004) Detection of molecular diversity in Bacillus atrophaeus by amplified fragment length polymorphism analysis. Appl Environ Microbiol 70(5):2786-2790

Carlson CR, Johansen T, Lecadet M-M, Kolstø A-B (1996) Genomic organization of the entomopathogenic bacterium Bacillus thuringiensis subsp. Berliner 1715. Microbiology 142:1625-1634

Cerón J, Covarrubias L, Quintero R, Ortiz A, Ortiz M, Aranda E, Lina L, Bravo A (1994) PCR analysis of the cryl insecticidal crystal family genes from Bacillus thuringiensis. Appl Environ Microbiol 60:353-356

Cerón J, Ortiz A, Quintero R, Güereca L, Bravo A (1995) Specific PCR primers to identify cryl and crylll genes within a Bacillus thuringiensis strain collection. Appl Environ Microbiol 61:3826-3831 
Chak K-F, Chao D-G, Tseng M-Y, Kao S-S, Tuan S-J, Feng T-Y (1994) Determination and distribution of cry-type genes of Bacillus thuringiensis isolates from Taiwan. Appl Environ Microbiol 60:2415-2420

Cruz CD (2001) Programa genes: versão windows; aplicativo computacional em genética e estatística. UFV, Viçosa, MG, p 648

Cruz CD, Carneiro PCS (2006) Modelos Biométricos Aplicados ao Melhoramento Genético, 2nd edn. UFV, Viçosa, MG

De Maagd RA, Bosch D, Stiekema W (1999) Bacillus thuringiensis toxin-mediated insect resistance in plants. Trends Plant Sci 4:9-13

Efron B, Tibshirani R (1993) An Introduction to the Bootstrap. Chapman \& Hall, Boca Raton

Fagundes RBS, Picoli EAT, Lana UGP, Valicente FH (2011) Plasmid patterns of efficient and inefficient strains of Bacillus thuringiensis against Spodoptera frugiperda (J.E. Smith) (Lepidoptera: Noctuidae). Neotrop Entomol 40(5):600-606

Glare TR, O'Callaghan M (2000) Bacillus Thuringiensis: Biology, Ecology and Safety. John Wiley \& Sons, Ltd, West Sussex, UK, p 350p

Grady R, Blanc D, Hauser P, Stanley J (2001) Genotyping of European isolates of methicillin-resistant Staphylococcus aureus by fluorescent amplified-fragment length polymorphism analysis (FAFLP) and pulsed-field gel electrophoresis (PFGE) typing. J Med Microbiol 50:588-593

Hill KK, Ticknor LO, Okinaka RT, Asay M, Blair H, Bliss KA, Laker M, Pardington PE, Richardson AP, Tonks M, Beecher DJ, Kemp JD, Kolsto A, Wong ACL, Keim P, Jackson PJ (2004) Fluorescent amplified fragment length polymorphism analysis of Bacillus antracis, Bacillus cereus and Bacillus thuringiensis isolates. Appl Environ Microbiol 70(2):1.068-1.080

Hossain MA, Ahmed S, Hoque S (1997) Abundance and distribution of Bacillus thuringiensis in the agricultural soil of Bangladesh. J Invertebr Pathol 70:221-225

Jansen P, Maquelin K, Coopman R, Tjernberg I, Bouvet P, Kersters K, Dijkshoorn L (1997) Discrimination of Acinetobacter genomics species by AFLP fingerprinting. Int J Syst Bacteriol 47:1179-1187

Kumar PA, Sharma RP, Malik VS (1996) The insecticidal proteins of Bacillus thuringiensis. Ad App Microbiol 42:1-43

Lereclus D, Ribier J, Klier A, Menou G, Lecadet M-M (1984) A transposon-like structure related to the bendotoxin gene of Bacillus thuringiensis. EMBO J 3:2561-2567

Lima ASG, Guidelli AM, Abreu IL, Lemos MVF (2002) Identification of new isolates of Bacillus thuringiensis using rep-PCR products and $\delta$-endotoxin electron microscopy. Genet Mol Biol 25(2):225-229

Martin PA, Travers RS (1989) Worldwide abundance and distribution of Bacillus thuringiensis isolates. Appl Environ Microbiol 55:2437-2442

Ryu C, Lee K, Hawng H, Yoo C, Seong W, Oh H (2005) Molecular characterization of Korean Bacillus anthracis isolates by amplified fragment length polymorphism analysis and Multilocus Variable-Number Tandem Repeat analysis. App Environ Microbiol Wash 71(8):4.664-4.671

Shangkuan YH, Chang YH, Yang J-F, Lin H-C, Shaio M-F (2001) Molecular characterization of Bacillus anthracis using multiplex PCR, ERIC-PCR and RAPD. Lett Appl Microbiol 32(3):139-145

Shuhaimi M, Ali AM, Saleh NM, Yazid AM (2001) Utilisation of eterobacterrial repetitive intergenic consensus (ERIC) sequence-based PCR to fingerprint the genomes of Bifidobacterium isolates and other probiotic bacteria. Biotechnol Lett 23(9):731-736

Valicente FH, Barreto MR (2003) Bacillus thuringiensis survey in Brazil: geographical distribution and insecticidal activity against Spodoptera frugiperda (J.E. Smith) (Lepidoptera: Noctuidae). Neotrop Entomol 32(4):639-644

Valicente FH, Fonseca MM (2004) Susceptibilidade da lagarta-do-cartucho do milho, Spodoptera frugiperda, a diferentes isolados de Bacillus thuringiensis. Rev Bras Milho e Sorgo 3:21-29

Valicente FH, Edgard ATP, Maria JW, Newton PC, Andréia AC, Cláudia TG, Ubirac GL (2010) Molecular characterization and distribution of Bacillus thuringiensis cryl genes from Brazilian strains effective against the fall armyworm, Spodoptera frugiperda. Biol Control 53:360-366

Vidyarthi AS, Tyagi RD, Valero JR, Surampalli RY (2002) Studies on the production of $B$. thuringiensis based biopesticides using wastewater sludge as a raw material. Water Res 36:4850-4860

Vilas-Boas G, Sanchis V, Lereclus D, Lemos MVF, Bourguet D (2002) Genetic differentiation between sympatric populations of Bacillus cereus and Bacillus thuringiensis. Appl Environ Microbiol 68:1414-1424
Vos P, Hogers R, Bleeker M, Reijans M, Lee TV, Hornes M, Frijters A, Pot J, Kuipe M, Zabeau M (1995) AFLP a new technique for DNA fingerprinting. Nucleic Acids Res 23:4407-4414

Yamamoto T, Dean DH (2000) Insecticidal Proteins Produced by Bacteria Pathogenic to Agriculturas Pests. In: Charles JF, Delécluse A, Nielsen-LE Roux $C$ (eds) Entomopathogenic Bacteria: From Laboratory to Field Application. Kluwer Academic Publishers, Netherlands, pp 81-100

Zeigler DR (1999) Bacillus Thuringiensis and Bacillus Cereus: Catalog of Strains. Bacillus Genetic Stock Center, Columbus

\section{doi:10.1186/2193-1801-3-256}

Cite this article as: Valicente and da Silva: fAFLP analysis of Brazilian

Bacillus thuringiensis isolates. SpringerPlus 2014 3:256.

\section{Submit your manuscript to a SpringerOpen ${ }^{\odot}$ journal and benefit from:}

- Convenient online submission

- Rigorous peer review

- Immediate publication on acceptance

- Open access: articles freely available online

- High visibility within the field

- Retaining the copyright to your article

Submit your next manuscript at $>$ springeropen.com 